\title{
Polyphosphates as a source of enhanced $P$ fluxes in marine sediments overlain by anoxic waters: Evidence from ${ }^{31} P$ NMR
}

\author{
Poulomi Sannigrahi and Ellery Ingall \\ School of Earth and Atmospheric Sciences, Georgia Institute of Technology, 311 Ferst Drive, \\ Atlanta, Georgia 30332-0340
}

(Received 10 February 2005; accepted 12 May 2005; published 22 June 2005)

\begin{abstract}
Sedimentary phosphorus $(\mathrm{P})$ composition was investigated in Effingham Inlet, a fjord located on the west coast of Vancouver Island in Barkley Sound. Solid-state ${ }^{31} \mathrm{P}$ nuclear magnetic resonance (NMR) spectroscopy was applied to demineralized sediment samples from sites overlain by oxic and anoxic bottom waters. The two sites were similar in terms of key diagenetic parameters, including the mass accumulation rate, integrated sulfate reduction rate, and bulk sediment organic carbon content. In contrast, $\mathrm{P}$ benthic fluxes were much higher at the anoxic site. ${ }^{31} \mathrm{P}$ NMR results show that $\mathrm{P}$ esters and phosphonates are the major organic $\mathrm{P}$ species present at the surface and at depth in sediments at both sites. Polyphosphates were only found in the surface sediment of the site overlain by oxic waters. The varying stability of polyphosphates in microorganisms under different redox conditions may, in part, explain their distribution as well as differences in P flux between the two sites. (c) 2005 American Institute of Physics. [DOI: 10.1063/1.1946447]
\end{abstract}

\section{INTRODUCTION}

Phosphorus (P) is an essential and in many cases limiting nutrient sustaining marine primary productivity. The burial of $\mathrm{P}$ compounds resistant to remineralization during diagenesis is a significant sink in the global marine $\mathrm{P}$ budget. ${ }^{1-6}$ The global biogeochemical cycle of $\mathrm{P}$ may be affected by shifts in the extent of oxic/anoxic regions within ocean models. ${ }^{7-11}$ The release and benthic flux of $\mathrm{P}$ from sediments relative to carbon $(\mathrm{C})$ and nitrogen $(\mathrm{N})$ remineralization may change significantly as a function of bottomwater oxygen availability. Evidence from the direct measurement of benthic fluxes or fluxes calculated from pore water profiles suggests that the presence of anoxic bottom waters enhances the release of $\mathrm{P}$ (as compared to $\mathrm{N}$ and $\mathrm{C}$ ) from organic matter. ${ }^{12-14}$ The preferential regeneration of $\mathrm{P}$ from sediments overlain by anoxic bottom waters has also been suggested from studies of solid phase P distribution. ${ }^{15-20}$ However, this hypothesis remains controversial, as other studies propose that the net effect of anoxia on P release is not as significant. ${ }^{1,5,21-23}$ This controversy may be resolved in part with a better understanding of redox sensitive mechanisms involved in $\mathrm{P}$ cycling.

The sensitivity of $P$ flux and burial in sediments to bottom water oxygen levels has commonly been explained by the cycling of $\mathrm{P}$ associated with reducible ferric oxyhydroxide phases. ${ }^{3,6,14,24}$ The reduction of ferric oxyhydroxide phases in sediments in response to decreasing redox potential results in the release of dissolved ferrous iron and $\mathrm{P}$ to sediment pore waters and ultimately to overlying waters. However, it is also possible that a large fraction of the P released in response to decreasing redox potential originates directly from benthic microorganisms rather than ferric hydroxides. ${ }^{25}$ The storage and release of $\mathrm{P}$ (in the form of intracellular polyphosphate granules) by certain bacteria and protozoan genera has been suggested as an explanation, ${ }^{15,25-28}$ but direct evidence for this process in marine sediments has been limited. ${ }^{29}$ In addition to redox sensitive $\mathrm{P}$ cycling mechanisms, very little is known about organic $\mathrm{P}$ speciation as a function of redox conditions. ${ }^{22,30}$

In this study, we present results from solid-state ${ }^{31} \mathrm{P}$ NMR spectroscopic characterization of organic matter in demineralized sediments from sites overlain by anoxic and oxic waters in the Effingham inlet, British Columbia (Fig. 1). The sites in Effingham Inlet are separated by only $1 \mathrm{~km}$ and

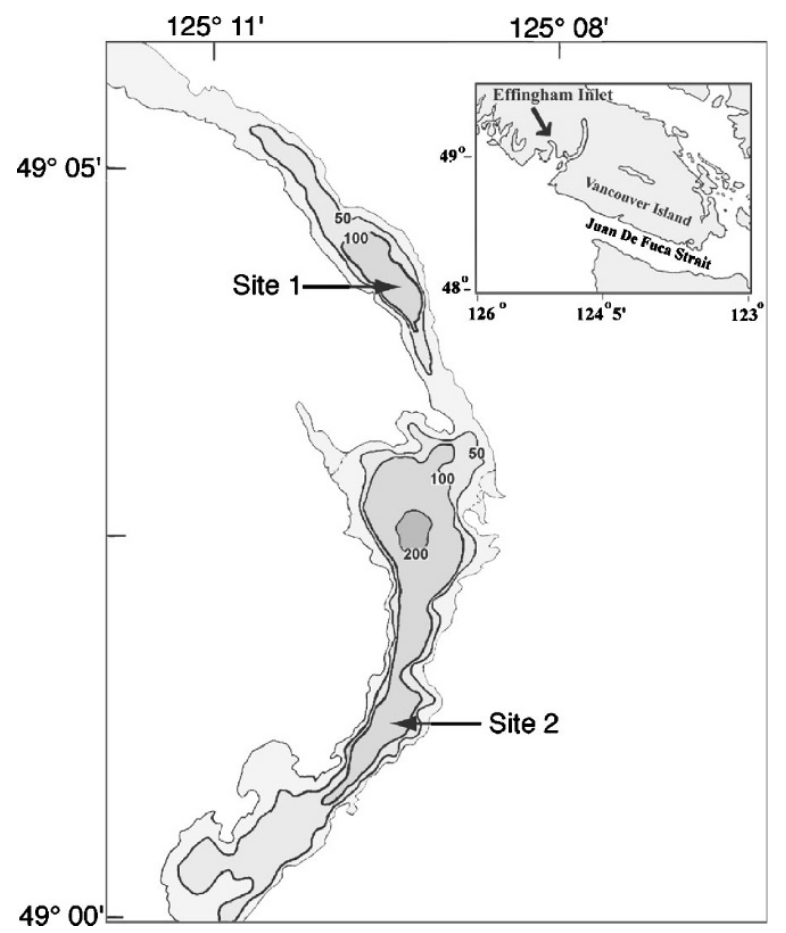

FIG. 1. Map of Effingham Inlet displaying sampling Sites 1 and 2. The water column at sampling Site 1 (called the anoxic site in the text) is anoxic below a depth of $65 \mathrm{~m}$. Waters at Site 2 (referred to as the oxic site in the text) contain oxygen at the sediment-water interface. The inset map shows the relation of Effingham Inlet to Barkley Sound on the west coast of Vancouver Island. 


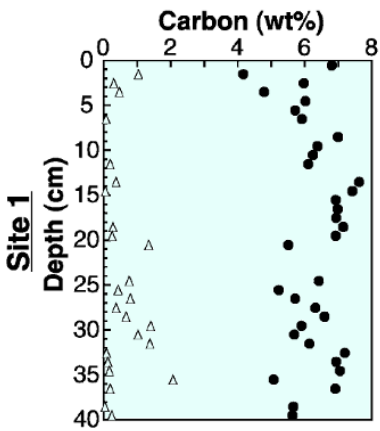

Phosphorus $(\mu \mathrm{mol} / \mathrm{g})$
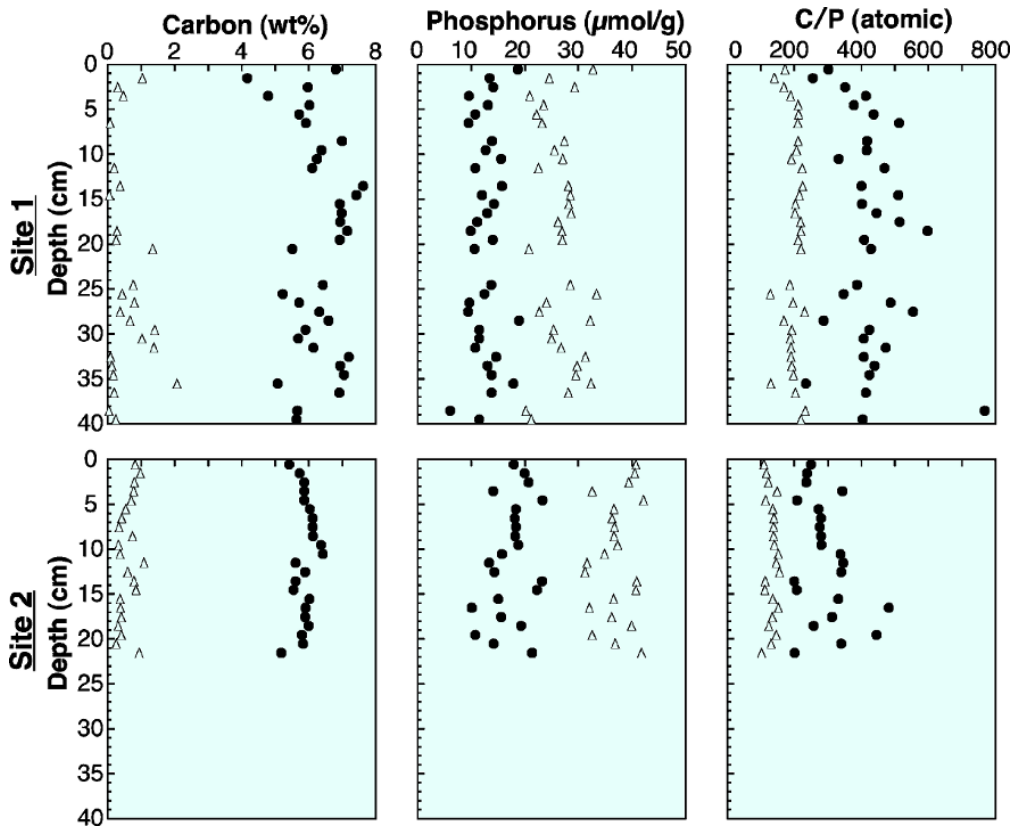

FIG. 2. (Color) Sediment solid phase inorganic carbon (triangles), organic carbon (circles); organic phosphorus (circles), total phosphorus (triangles); organic $\mathrm{C} /$ total $\mathrm{P}$ (triangles) and organic $\mathrm{C}$ /organic $\mathrm{P}$ (circles) atomic ratio distributions for Sites 1 and 2 in Effingham Inlet. Data presented are from natural sediments and are taken from Ingall et al. (Ref. 16). were similar in terms of key diagenetic parameters, including the mass accumulation rate and bulk sediment organic carbon content ${ }^{16}$ (Fig. 2). The similarities in these key parameters allow a focus on diagenetic effects attributable to depositional oxygen availability. These diagenetic effects include differences in $\mathrm{P}$ benthic flux, total and organic $\mathrm{P}$ concentration and elemental $\mathrm{C}: \mathrm{P}$ ratio of the sediments ${ }^{16}$ (Fig. 2). NMR data as well as simple calculations suggest that the storage and release of biogenic inorganic $\mathrm{P}$ in the form of polyphosphate by certain microorganisms under oscillating oxic anoxic conditions can account for some of the differences in $\mathrm{P}$ fluxes and sediment characteristics between the two sites.

\section{METHODS}

\section{A. Study site}

Effingham Inlet is a fjord on the southwestern coast of Vancouver Island, British Columbia, which opens in to the Imperial Eagle Channel in eastern Barkley Sound. It is approximately $17 \mathrm{~km}$ long and $1 \mathrm{~km}$ in width along its entire length. Depth profiles for Effingham Inlet indicate the presence of two sills. The outer basin, which reaches a depth of approximately $210 \mathrm{~m}$, is located behind the outer sill, which is at $70 \mathrm{~m}$ water depth (Fig. 1). The inner sill is located at approximately $149^{\circ} 03^{\prime} \mathrm{N}$ and $40 \mathrm{~m}$ water depth. The inner basin, which reaches a depth of about $120 \mathrm{~m}$, is located behind this sill. The shallow sills, low wind mixing rates, and cool dense saline waters of the deep portions of the inner and outer basins collectively inhibit ventilation of basin subsurface waters. The reduced subsurface water replacement rates probably lead to long deep-water residence times, which are consistent with measurements of water column anoxia in the inner and outer basins. ${ }^{16}$

Sediments from two sites at approximately $120 \mathrm{~m}$ water depth in the Effingham Inlet were collected during a cruise aboard the R/V Barnes during May and June of 1997 (Fig. 1). Site 1 is located in the deepest part of the inner basin. The sediments at this site were black, fine-grained microlaminated muds. The black coloration of sediments record anomalous enrichments in acid-volatile sulfide. ${ }^{31}$ The oxygen concentration in the water column at site 1 decreases to 0 at a depth of $65 \mathrm{~m}$ (Fig. 3). Sediment characteristics such as laminations coupled with measured accumulation rates (using the ${ }^{210} \mathrm{~Pb}$ and ${ }^{137} \mathrm{Cs}$ techniques) suggest that bottom waters at this site have remained anoxic for at least the last 60 years. ${ }^{16}$ Site 2 is located at the southern edge of the outer basin. The Site 2 water column was also characterized by decreasing oxygen concentrations with depth (Fig. 3). However, in contrast to Site 1, bottom waters at Site 2 remained
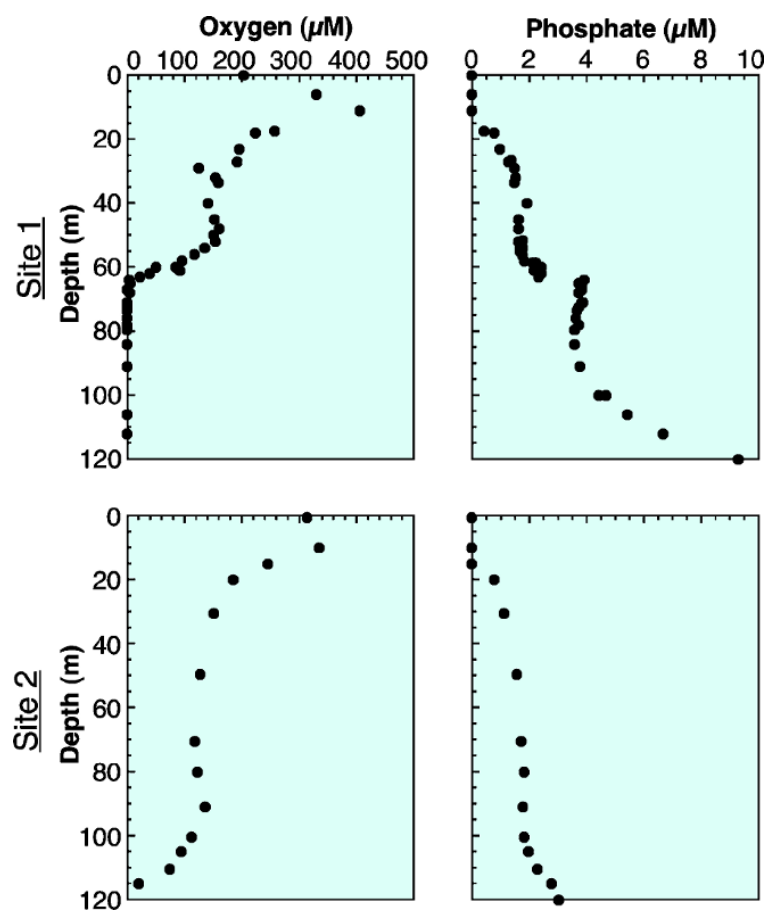

FIG. 3. (Color) Water column distributions of dissolved oxygen, and phosphate for Sites 1 and 2 in Effingham Inlet. Data presented are from Ingall et al. (Ref. 16). 
oxic with oxygen concentrations of approximately $8 \mu \mathrm{M}$ at the sediment-water interface (Fig. 3). Cores taken at Site 2 consist of homogenized, grey-brown, fine-grained muds. Consistent with the presence of bottom water oxygen, small infauna and mm-scale burrows were observed in Site 2 cores, and these cores had no visible evidence of lamination. An additional description of sediments from both sites can be found in Hurtgen et al. ${ }^{31}$ and Ingall et al. ${ }^{16}$ Site 1 is referred to as the anoxic site and Site 2 as the oxic site hereafter in the text.

\section{B. Sample collection and processing procedures}

All sediment cores were collected using a gravity corer and sliced at $1 \mathrm{~cm}$ intervals under a $\mathrm{N}_{2}$ atmosphere at $\sim 8{ }^{\circ} \mathrm{C}$, the ambient bottom-water temperature. These samples were placed in plastic dishes and frozen for later analyses. Prior to chemical analyses, sediment samples were freeze dried and then ground using an agate mortar and pestle. Samples from 2 depths from each site, one from the surface and one deeper in the sediment column were chosen to evaluate the effect of diagenesis on $\mathrm{P}$ speciation. The samples taken at depth at each site had organic $\mathrm{C}$ and $\mathrm{P}$ concentrations close to the average values for each core (Fig. 2).

Low organic C concentrations coupled with potentially high concentrations of paramagnetic metals in soils and sediments often lead to poor quality NMR spectra. ${ }^{32}$ In order to obtain NMR spectra using reasonable amounts of spectrometer time, a demineralization procedure developed by Gélinas et al. $^{32}$ was adopted to remove paramagnetic metals and mineral phases (carbonates and silicates) and concentrate the organic fraction. Between 0.7 to $0.9 \mathrm{~g}$ of dried sediment was weighed directly into $50 \mathrm{ml}$ polystyrene centrifuge tubes with screw caps. In order to dissolve salt, carbonate, and sesquioxide coatings, $30 \mathrm{ml}$ of $1 \mathrm{~N} \mathrm{HCl}$ were added, and the samples were agitated for $1 \mathrm{~h}$ at room temperature. Residues were recovered by centrifugation and rinsed three times with a total of $20 \mathrm{ml}$ of deionized water. The sediment fraction remaining after $\mathrm{HCl}$ treatment was treated with a $1 \mathrm{~N} \mathrm{HCl}$ and $10 \%(\mathrm{v} / \mathrm{v}) \mathrm{HF}$ solution to dissolve the silicates. A $20 \mathrm{ml}$ aliquot of the $\mathrm{HCl} / \mathrm{HF}$ solution was added to the sediment, and the mixture was shaken for $12 \mathrm{~h}$ at room temperature. The supernatant was removed by centrifugation, and the same treatment was repeated a second time. After removing the second supernatant, the residue was washed three times with a total of $10 \mathrm{ml}$ of deionized water. The sediment fraction remaining after the treatment was freeze dried and ground with an agate mortar and pestle. Given the high organic carbon content of the Effingham sediments ( $c a$. $6 \mathrm{wt}$. $\%)$, the protocols for samples with high organic carbon contents $(>1 \%)$ specified by Gelinas et al. ${ }^{32}$ where the supernatants from the $\mathrm{HCl}$ and $\mathrm{HCl} / \mathrm{HF}$ treatments are not recombined with the final organic fraction, were followed. The organic $\mathrm{C}, \mathrm{N}$, and $\mathrm{P}$ contents of the demineralized sediments were measured. $^{33,34}$ The results indicate that the molecular composition of the organic fraction, as represented by the organic $\mathrm{C} / \mathrm{N}$ atomic ratios, is not appreciably altered during the demineralization procedure. The organic $\mathrm{C} / \mathrm{N}$ atomic ra- tios of the demineralized samples were only $1 \%-5 \%$ higher than the natural sediments. These results agree with those of Gelinas et al. $^{32}$ However, the organic $\mathrm{P}$ contents and organic $\mathrm{C} / \mathrm{P}$ atomic ratios show that there is a preferential loss of organic $\mathrm{P}$ from these samples following demineralization. The organic $\mathrm{C} / \mathrm{P}$ atomic ratios of the demineralized sediments are $20 \%-45 \%$ higher than the unprocessed samples. Thus, it appears that despite the relatively high organic $\mathrm{C}$ contents of these sediments, the supernatants from the $\mathrm{HCl}$ and $\mathrm{HCl} / \mathrm{HF}$ treatments should be combined with the final organic fraction for future studies. Although $\mathrm{P}$ is lost relative to $\mathrm{C}$ during demineralization, this procedure is very unlikely to create or hydrolyze polyphosphates and phosphonates, which are resistant to acid hydrolysis. ${ }^{35-37}$ These compound classes are usually extracted using alkaline treatments ${ }^{36,37}$ or high-temperature acid treatments. ${ }^{38}$ However, it is likely that the labile $\mathrm{P}$ compounds such as $\mathrm{P}$ esters ${ }^{39}$ are preferentially remineralized and more resistant compounds such as polyphosphates and phosphonates may be concentrated relative to them in the demineralized samples.

Solid-state ${ }^{31} \mathrm{P}$ NMR analyses of the sediment samples were carried out at the NMR center in the School of Chemistry and Biochemistry at the Georgia Institute of Technology. The ${ }^{31} \mathrm{P}$ NMR spectra were acquired on a Bruker DSX 400 spectrometer using Cross Polarization-Magic Angle Spinning (CP-MAS) at a ${ }^{31} \mathrm{P}$ frequency of $161 \mathrm{MHz}$. Approximately $90 \mathrm{mg}$ of powdered sample was packed into a 4 $\mathrm{mm}$ diameter cylindrical zirconia rotor fitted with a Kel-F cap and spun at $10000 \pm 10 \mathrm{~Hz}$ in a Bruker magic-angle spinning probe. The presence of spinning sidebands is an artifact of MAS, but at fast enough spinning rates such as the one used here, they do not interfere with the peak resonances. For all samples, a cross-polarization sequence, optimized to obtain semiquantitative data, was used with a 1.0 $\mathrm{ms}$ contact time and a pulse delay of $4 \mathrm{~s}$. In order to obtain semiquantitative data using CP-MAS techniques, the time delay between two consecutive NMR pulses (referred to as the pulse delay), used should be much greater than the spinlattice relaxation times $\left(T_{1 \rho} H\right.$ 's) of all the different functional groups present. ${ }^{40}$ In complex material such as natural organic matter, where a range of $T_{1 \rho} H$ 's are present, NMR optimization experiments have to be performed to determine an optimal value of pulse delay that satisfies the above condition. The presence of paramagnetic material in natural samples usually helps lower the relaxation times and thus more scans can be acquired in a given amount of time. In a series of experiments performed on marine dissolved organic matter samples, Clark ${ }^{41}$ found that varying the pulse delay from 1 to $20 \mathrm{~s}$ did not appear to alter the relative peak areas of the P-ester and phosphonate peaks, suggesting that $4 \mathrm{~s}$ was a sufficient pulse delay for these peaks to relax in the sample matrix. A contact time of $1 \mathrm{~ms}$, commonly used for natural organic matter samples, was found to be optimal in this case as well. A total of 32000 transients were collected for each sample, and the spectra were processed with $100 \mathrm{~Hz}$ line broadening. The data processing and calculation of integrated peak areas were carried out off-line using the Mestre-C software package (Mestrelab Research, Santiago de Compostela, Spain). The peaks present in the solid-state 


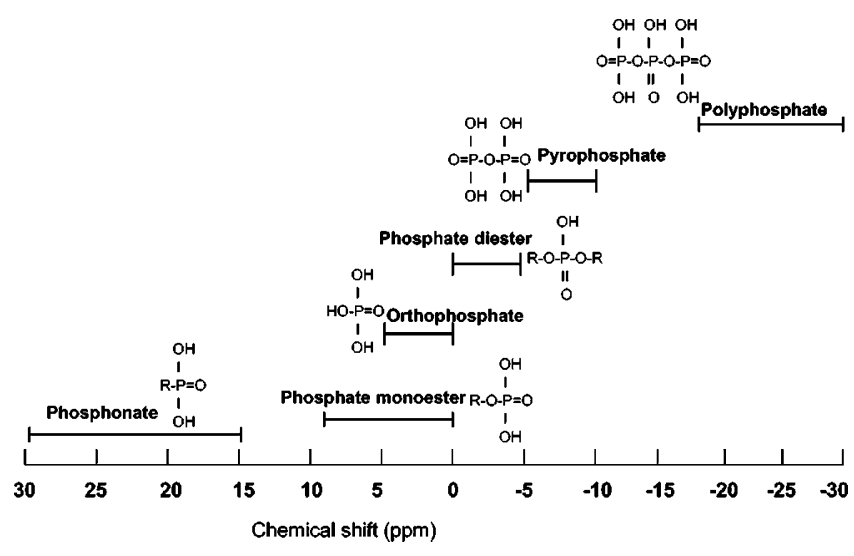

FIG. 4. ${ }^{31} \mathrm{P}$ NMR chemical shift ranges (on the ppm scale) and chemical structures of common P functional groups observed in natural samples.

${ }^{31} \mathrm{P}$ NMR spectra were accepted for further analyses only if their signal to noise ratios (as determined using the Mestre-C software) were greater than 4. The identification of functional groups by ${ }^{31} \mathrm{P}$ NMR is based on their chemical shift relative to an external phosphoric acid standard. Chemical shift values are used to represent differences in resonance frequency of different $\mathrm{P}$ compound classes. These values are dimensionless and are expressed in parts per million (ppm) relative to the phosphoric acid standard set at $0 \mathrm{ppm}$. Figure 4 illustrates the chemical structures and ${ }^{31} \mathrm{P}$ NMR chemical shift ranges of common $\mathrm{P}$ functional groups in both natural and standard materials as compiled from the literature. ${ }^{27,42-44}$ Using the Mestre-C software package, peak areas between selected ppm ranges corresponding to different $\mathrm{P}$ functional groups (Fig. 4) can be integrated. The software returns absolute peak areas relative to a reference peak (whose area is set as 1). Percentage peak areas of individual peaks are then calculated by dividing their areas by the total spectral peak area of the sample. Using the Mestre-C software rather than manual integration, ensures that the spectral limits are chosen precisely for all spectra. The errors associated with solidstate ${ }^{13} \mathrm{C}$ CP-MAS NMR measurements and peak area determinations are on the order of $10 \% .^{45,46}$ Given that NMR parameters such as contact time and recycle delay were optimized using a similar procedure to the ${ }^{13} \mathrm{C}$ measurements, and the analyses were carried out on the same instrument, it is expected that errors in ${ }^{31} \mathrm{P}$ will be of a similar magnitude.

\section{RESULTS AND DISCUSSION}

\section{A. ${ }^{31} \mathrm{P}$ NMR results}

Solid-state ${ }^{31} \mathrm{P}$ NMR spectra of demineralized sediment samples from Effingham Inlet are presented in Figs. 5 and 6. The most prominent feature observed in all the spectra is the peak centered at around $-3 \mathrm{ppm}$. Peaks in the chemical shift range $(10$ to $-10 \mathrm{ppm})$ are primarily attributed to $\mathrm{P}$ esters. Resonances on the right (upfield) side of this central peak are attributed to $\mathrm{P}$ diesters, pyrophosphates, and end groups of polyphosphates (Fig. 4). Peak area integrations (Table I) indicate that $\mathrm{P}$ esters comprise the major percentage of $\mathrm{P}$ in the demineralized sediments. Phosphate monoesters are present in biomolecules such as mononucleotides, sugar phosphates, and inositol phosphate, whereas diesters occur in phospholipids and nucleic acids. ${ }^{43}$ The abundance of $\mathrm{P}$ esters in natural organic matter is undoubtedly related to the synthesis of these compounds by all living organisms, and they are typically the most abundant compound class seen in studies from both marine and terrestrial environments. ${ }^{36,44,47}$

A comparison of the prominent P-ester peak for the sediments from the oxic and anoxic sites indicates that it is broader in the upfield region of the spectrum for the oxic sediments. Small peaks on the right shoulder of the central peak can also be seen in the spectra of the oxic site sediments. The asymmetric shape of the P-ester peak and the presence of these smaller peaks suggest that phosphate diesters, pyrophosphates, and polyphosphates (end groups) may be more abundant in sediments from the oxic site. Pyrophosphates have been observed in zooplankton and phytoplankton samples. ${ }^{48}$ Small pyrophosphate peaks have also been seen in ${ }^{31} \mathrm{P}$ NMR spectra of marine sinking particulate material. ${ }^{43,49}$ In a comparative study of sediments from oxic and anoxic sites in the Baltic Sea by Carman et al., ${ }^{30}$ pyrophosphates were only present in sediments from oxic sites. The results of Carman et al. ${ }^{30}$ and this study are consistent and suggest that the presence of pyrophosphates may be sensitive to redox conditions.

Phosphonates, a group of compounds containing a direct C-P bond, are also present in the Effingham Inlet sediments, as revealed by the peak at approximately $25 \mathrm{ppm}$ in all spectra (Figs. 5 and 6). The strong covalent C-P bonds in phosphonates make them resistant to chemical, thermal, and pho-

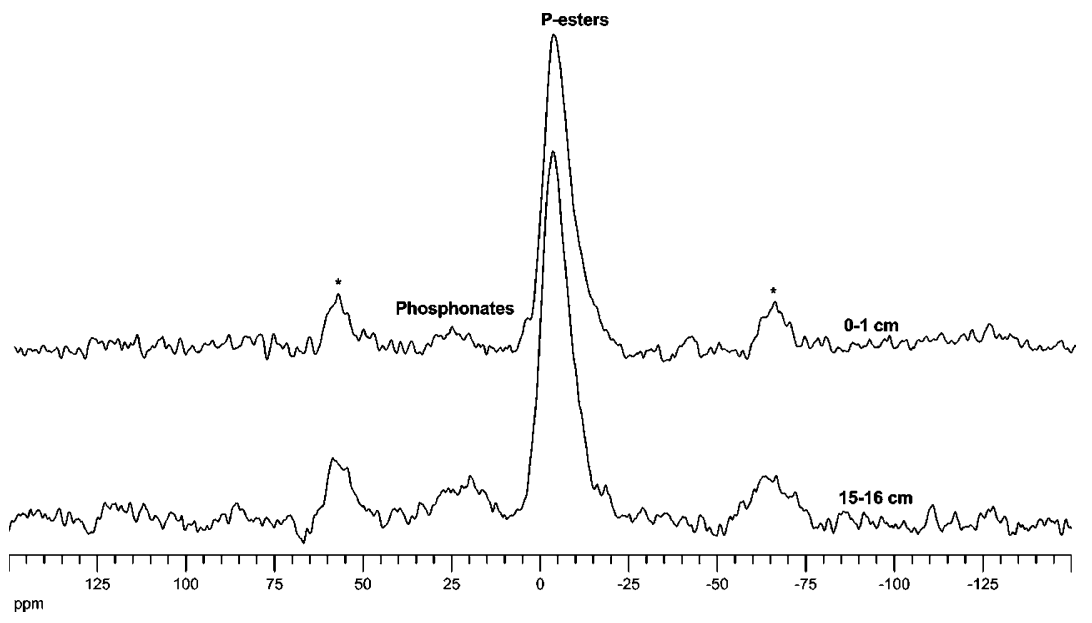

FIG. 5. Solid-state CP-MAS ${ }^{31}$ P NMR spectra of demineralized sediments from Site 1 stacked according to depth. Asterisks denote spinning sidebands. NMR operating parameters: Contact time $1 \mathrm{~ms}$; recycle delay $4 \mathrm{~s}$; 32780 transients. 


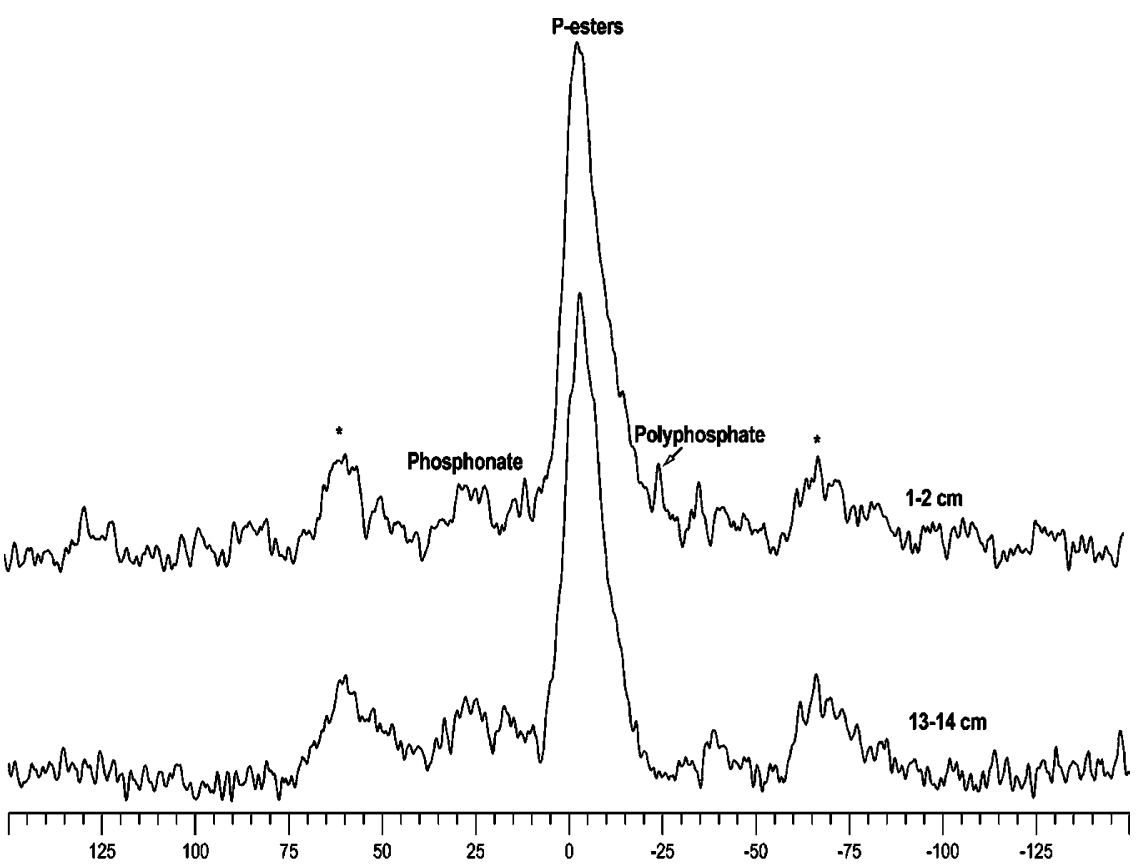

ppm

tolytic degradation. ${ }^{50,51}$ They occur widely among biogenic and anthropogenic compounds in the form of phosphonolipids and as side groups on polysaccharides and glycoproteins. Phosphonates comprise $6 \%-15 \%$ of the $\mathrm{P}$ in the sediments from both sites in the Effingham Inlet (Table I).

In both sites in the Effingham Inlet, the percentage of phosphonates shows a small increase with depth, suggesting no preferential removal relative to $\mathrm{P}$ esters (Table $\mathrm{I}$ ). This is in contrast to the results of Benitez-Nelson et al., ${ }^{22}$ who reported a decrease in the proportion of phosphonates relative to $\mathrm{P}$ esters in sinking particles as these particles sedimented from the oxic to anoxic portions of the Cariaco Basin water column. Carman et al. $^{30}$ also observed a small phosphonate signal ( $4 \%$ of $\mathrm{P})$ in sediments from an oxic site in the Baltic Sea, but none from the anoxic site. Experiments studying the uptake of dissolved $\mathrm{P}$ suggest that $\mathrm{P}$ esters should be more bioavailable than phosphonates. ${ }^{39}$ In marine waters, $\mathrm{P}$ esters can be utilized by algae as well as bacteria, but only bacteria have demonstrated the capability of cleaving C-P bonds. The most common enzymatic pathway of bacterial phosphonate degradation involves the enzyme $\mathrm{C}$-P lyase that catalyzes the direct cleavage of the $\mathrm{C}-\mathrm{P}$ bond to produce the corresponding alkane and phosphate. Only special strains, rather than certain groups of prokaryotic microorganisms, are able to cleave the C-P bond. ${ }^{50}$ The ability to degrade phosphonates by the

TABLE I. Relative percentages of the total ${ }^{31} \mathrm{P}$ NMR peak area represented by different $\mathrm{P}$ functional groups in samples from different depths in sites 1 and 2 .

\begin{tabular}{cccc}
\hline \hline Site 1 & P esters & Phosphonate & Polyphosphate \\
\hline $0-1 \mathrm{~cm}$ & 94 & 6 & 0 \\
$15-16 \mathrm{~cm}$ & 86.6 & 13.4 & 0 \\
Site 2 & & & \\
$1-2 \mathrm{~cm}$ & 82 & 10 & 0 \\
$13-14 \mathrm{~cm}$ & 85 & 15 & 0 \\
\hline \hline
\end{tabular}

FIG. 6. Solid-state CP-MAS ${ }^{31} \mathrm{P}$ NMR spectra of demineralized sediments from Site 2 stacked according to depth. Asterisks denote spinning sidebands. NMR operating parameters: Contact time $1 \mathrm{~ms}$; recycle delay $4 \mathrm{~s}$; 32780 transients.
C-P lyase mechanism is more prevalent among Gramnegative bacteria than Gram-positive bacteria. ${ }^{50}$ Thus, the conflicting observations over the stability of phosphonates under anaerobic conditions may be a reflection of differences in the microorganisms present at different locations.

The solid-state ${ }^{31} \mathrm{P}$ NMR spectrum from the surface sediments at the oxic site in Effingham Inlet shows the presence of inorganic phosphates in the form of a distinct polyphosphate peak signal at $-25 \mathrm{ppm}$ (Fig. 6). This peak is not observed in any of the other spectra (Figs. 5 and 6) and is attributed to polyphosphate middle groups. ${ }^{27}$ The end groups of polyphosphate chains occur at around the same region in the NMR spectra as pyrophosphates $(\sim-10 \mathrm{ppm})$ and cannot be resolved from the latter using solid-state NMR spectroscopy. The presence of polyphosphate has also been reported in marine sinking particles and sediments ${ }^{43,52}$ and lacustrine sediments. $^{27,30}$ In our samples, polyphosphate comprised $8 \%$ of the $\mathrm{P}$ in the $1-2 \mathrm{~cm}$ sediment from the oxic site, but was not detected in the deeper sample (Table I). Similar trends have also been seen in lake sediments, where polyphosphate accounted for up to $11 \%$ of the total $\mathrm{P}$ in the top $0.5 \mathrm{~cm}$, but were not observed in deeper sediments. ${ }^{27}$ The middle groups of polyphosphate chains are more susceptible to degradation than the end groups, which could explain their rapid disappearance from deeper sediments. ${ }^{27}$

\section{B. Polyphosphate synthesis and diagenesis}

Some microorganisms such as certain bacteria and yeast are able to store and accumulate $\mathrm{P}$ as intracellular polyphosphate granules. Polyphosphates have been reported to account for $30 \%$ of the cellular phosphate of two different plankton species Skeletonema costatum and Amphidinium carteri. ${ }^{35}$ Polyphosphate chains in certain bacteria such as $E$. coli can have a length of up to 1000 phosphate groups. ${ }^{53}$ Accumulation of polyphosphate occurs under aerobic conditions when excess dissolved $\mathrm{P}$ is available. If these microor- 
ganisms are exposed to an anaerobic environment, the stored $\mathrm{P}$ is utilized as an energy source and is eventually released in dissolved form to the surrounding waters. ${ }^{26,27,29}$ Polyphosphate accumulating organisms are dominant under oscillating redox conditions in waste water treatment plants involving biological $\mathrm{P}$ removal. ${ }^{27}$ The presence of higher amounts $(6.6 \%)$ of polyphosphate has also been documented in marine sediments deposited under fluctuating redox conditions in the Santa Monica basin. ${ }^{52}$ Several bacterial genera (e.g., Escherecia, Bacillus, Flavobacterium, and Pseudomonas) and protozoans (e.g., Vorticella, Opercularia, and Epistylis) have the ability to take up $\mathrm{P}$ and form intracellular polyphosphate under appropriate conditions of external $\mathrm{P}$ and oxygen availability.

Polyphosphates can be used as an energy source, a phosphate donor for sugars, and a chelator for divalent cations. Polyphosphate kinase and 1.3-diphosphoglycerolpolyphosphate phosphotransferase are two known polyphosphate synthesizing enzymes. Polyphosphatase and tripolyphosphatase are enzymes of polyphosphate degradation (see the review by Nesmeyanova ${ }^{53}$ ). In laboratory experiments with lake sediments and benthic microorganisms, an increase in the polyphosphate content and chain lengths was observed under aerobic conditions. ${ }^{27}$ Both the polyphosphate content and the chain length decreased under anaerobic conditions. A recent study by Schulz and Schulz ${ }^{29}$ provided comprehensive evidence for large benthic $\mathrm{P}$ fluxes resulting from polyphosphate utilization by the sulfide oxidizing bacterium Thiomargarita namibiensis in shelf sediments. Large amounts of polyphosphate inclusions were found in these bacteria under oxic conditions. Very high pore water phosphate concentrations (of up to $300 \mu \mathrm{M}$ ) were reported in a narrow region of sediments densely populated by $T$. namibiensis. Phosphate concentrations measured during an anaerobic incubation experiment confirmed that $T$. namibiensis alone could account for the observed pore water phosphate peak and resulting hydroxyapatite precipitation in the Namibian coast sediments. $^{29}$

In Effingham Inlet, high phosphate concentrations coupled with the availability of oxygen at the water column redox transition zone (at approximately $65 \mathrm{~m}$; Fig. 3) would provide an ideal environment for polyphosphate accumulation by microorganisms. The presence of polyphosphates in sediments from the oxic site suggests that polyphosphate accumulating microorganisms are transported and sedimented from the water column redox transition zone. Rapid and complete utilization of the sedimented polyphosphates at the sediment-water interface in the anoxic site may explain their absence at this site. Complete utilization at the sedimentwater interface would be consistent with extremely high sulfate reduction rates, indicating high levels of microbial activity in this region. ${ }^{16}$ At the oxic site, conditions at the sediment-water interface are not conducive for the utilization of polyphosphates. However, anoxic sediment conditions below a few $\mathrm{cm}$ at the oxic site would likely induce the utilization and subsequent disappearance of polyphosphates at depth.

In the sediments at the oxic site, $\mathrm{P}$ released during organic matter decomposition, polyphosphate metabolism, and the reduction of ferric oxides may be permanently sequestered via a number of mechanisms. One commonly described mechanism is related to the large sorption capacity of ferric oxyhydroxide particles for phosphate. ${ }^{3,6,14,24}$ When these iron oxyhydroxides are reduced, the associated phosphate is released. In sediments overlain by anoxic bottom waters the released iron and phosphate can diffuse out of the sediments. In contrast, the transition between oxidizing and reducing conditions is located within the sediments rather than in the water column, at the site overlain by oxic bottom waters. Oxic conditions in the upper few centimeters of the sediments prevent the reduction of ferric oxyhydroxides and the subsequent release of associated P. Additionally, in this situation, ferrous ions diffusing from the deeper anoxic regions of the sediment column can precipitate as ferric oxyhydroxides in the oxic upper sediment layers. These newly precipitated ferric oxyhydroxides can absorb and trap phosphate released during early diagenesis. Another potential mechanism for $\mathrm{P}$ trapping in oxic site sediments would be related to polyphosphate metabolism by organisms living at the oxicanoxic transition in the sediments. Polyphosphate metabolism occurs along a redox potential range that overlaps microbially mediated iron reduction. ${ }^{54}$ Thus, in a similar fashion to the cycling of iron and phosphate around the sediment oxic-anoxic transition, phosphate from polyphosphates remineralized in the deeper anoxic portions of the sediment could be sequestered by polyphosphate formation at the transition. The sequestration of phosphate by the above mechanisms would be consistent with the much lower pore water phosphate concentrations measured in the oxic site sediments as compared to those from the anoxic site. ${ }^{16}$

Ultimately, it is unlikely that either the iron cycling or polyphosphate metabolism mechanisms will permanently trap pore water phosphates in sediment columns overlain by oxic waters. Any phosphate trapped in ferric oxyhydroxides or polyphosphates in the oxic region of the sediments will be released upon burial in the anoxic region. Thus, a steadystate situation can develop where the amount of trapped $\mathrm{P}$ is related to the concentration of iron undergoing redox cycling and the activity of polyphosphate producing organisms. However, the permanent sequestration of $\mathrm{P}$ in sediments may be indirectly related to the intense cycling of $\mathrm{P}$ around the sediment redox transition. Cycling around the sediment redox transition can lead to extremely high pore water phosphate concentrations. When fluoride ions are readily available, such as under typical marine conditions, these high pore water phosphate concentrations can result in the precipitation of authigenic phosphate minerals such as apatite. ${ }^{5,55,56}$

The sequestration of $\mathrm{P}$ through authigenic mineral formation is consistent with the large difference in total phosphorus concentrations and $\mathrm{C} / \mathrm{P}$ ratios observed at the oxic and anoxic sites (Fig. 2). The average total phosphorus concentrations for the natural sediments are $37.1 \pm 3.5(\mu \mathrm{mol} / \mathrm{g})$ at the oxic site and $26.7 \pm 3.7(\mu \mathrm{mol} / \mathrm{g})$ at the anoxic site (Fig. 2; Ingall et al. $^{16}$ ). Sediments from the two sampling sites in the Effingham Inlet differ in terms of their organic $\mathrm{C}$ to total $\mathrm{P}$ ratios. The molar ratios of average organic $\mathrm{C}$ to average total $\mathrm{P}\left(\mathrm{C} / \mathrm{P}_{\text {tot }}\right)$ are 197 for the anoxic site and 133 
for the oxic site, indicating higher levels of $\mathrm{P}$ sequestration relative to $\mathrm{C}$ under oxic conditions (Fig. 2; Ingall et al. ${ }^{16}$ ).

\section{Relation between polyphosphate cycling and benthic $P$ flux}

The two sites have widely contrasting benthic $\mathrm{P}$ fluxes. The direct measurement of benthic P flux (using a benthic chamber) was successful only at the anoxic site and yielded a value of $0.69 \mathrm{~mol} / \mathrm{m}^{2} / \mathrm{y} .{ }^{19}$ At the oxic site, a benthic P flux of $0.032 \mathrm{~mol} / \mathrm{m}^{2} / \mathrm{y}$ was modeled from pore water phosphate measurements. ${ }^{16}$ The molar ratio of carbon oxidation to the benthic P flux at the anoxic site is 39 , which is well below the Redfield ratio for average marine organic matter and the observed solid phase organic $\mathrm{C}$ to organic $\mathrm{P}$ ratio of 410 in these sediments. ${ }^{16}$ These observations support the idea of the preferential remineralization of $\mathrm{P}$ relative to organic $\mathrm{C}$ during diagenesis in sediments overlain by anoxic bottom waters.

Calculations indicate that $\mathrm{P}$ release associated with the reduction of ferric oxyhydroxide particles and organic matter remineralization is insufficient to account for the observed $\mathrm{P}$ fluxes at the anoxic site. ${ }^{16}$ Total reactive iron concentrations, which are a measure of the total sulfidized iron, have values of 1.51 and $2.35 \mathrm{wt} . \%$ at the sediment-water interface at the anoxic and oxic sites, respectively. ${ }^{31}$ Assuming the iron in these sulfides ultimately originates from ferric oxyhydroxide reduction and dissolution, the difference in total reactive iron contents at the sediment-water interface represents the total amount of iron that is liberated during reduction and then sequestered as sulfides at the site overlain by anoxic bottom waters. The difference in total reactive iron concentrations between the two sites is $0.84 \mathrm{wt} . \%$. This value, together with an average sedimentation rate of $32.5 \mathrm{mg} / \mathrm{cm}^{2} / \mathrm{y}$ for the anoxic site, yields a reducible iron production rate of $0.05 \mathrm{~mol} / \mathrm{m}^{2} / \mathrm{y}$ for the sediments at this site. Although poorly constrained, an average ratio of iron to $\mathrm{P}$ in reducible ferric oxyhydroxide particles of 10.8 has been previously reported. ${ }^{15}$ Using this value, the benthic $\mathrm{P}$ flux resulting solely from the release of $\mathrm{P}$ from ferric oxyhydroxide particles is estimated to be $4.6 \times 10^{-3} \mathrm{~mol} / \mathrm{m}^{2} / \mathrm{y}$, which accounted for only $0.7 \%$ of the total P flux for the anoxic site.

$\mathrm{P}$ released during the oxidation of organic matter can also contribute to the benthic $\mathrm{P}$ fluxes. Using the average $\mathrm{C}$ oxidation rate of $27.3 \mathrm{~mol} / \mathrm{m}^{2} / \mathrm{y}$, the benthic P flux from the oxidation of Redfield organic matter $(\mathrm{C}: \mathrm{P}=106: 1)$ is calculated to be $0.25 \mathrm{~mol} / \mathrm{m}^{2} / \mathrm{y}$. This amounts to $36 \%$ of the $\mathrm{P}$ flux. These calculations suggest that either organic matter with a $\mathrm{C}: \mathrm{P}$ ratio significantly lower than Redfield $(<40)$ is being remineralized, or $\mathrm{P}$ is preferentially released relative to $\mathrm{C}$ during diagenesis, or other redox-sensitive $\mathrm{P}$ remineralization mechanisms must be acting in the Effingham Inlet in order to account for the $\mathrm{P}$ fluxes at the anoxic site. The explanation of a large contribution of low $\mathrm{C} / \mathrm{P}$ ratio organic matter is unlikely for the Effingham Inlet, where the water column microfauna is dominated by diatoms. ${ }^{57}$ An average molar C:P ratio of 129 has been reported for marine diatoms. ${ }^{58}$ Thus, it appears that oxidation of this diatom-rich organic matter alone cannot account for the measured benthic P flux.
Earlier studies have invoked the release of $\mathrm{P}$ from the degradation of polyphosphates as a potential source of $\mathrm{P}$ to explain the enhanced benthic $\mathrm{P}$ fluxes commonly observed under anoxic conditions. ${ }^{15,16,26-28}$ The availability of information on sedimentation rates and carbon fluxes for the Effingham Inlet site makes it possible to calculate the potential contribution of polyphosphate remineralization to the observed benthic P flux. It should be noted here that even though these calculations are not entirely quantitative, they are useful in estimating the relative significance of the different processes in explaining the observed $\mathrm{P}$ fluxes. The depositional flux of $\mathrm{C}$ to the sediments can be estimated from the sum of the $\mathrm{C}$ oxidation and $\mathrm{C}$ burial rates. Using measured sulfate reduction rates, Ingall et al. ${ }^{16}$ calculated an average $\mathrm{C}$ oxidation rate of $27.2 \mathrm{~mol} / \mathrm{m}^{2} / \mathrm{y}$. The $\mathrm{C}$ burial rate can be calculated using the measured mass accumulation rate $\left(32.5 \mathrm{mg} / \mathrm{cm}^{2} / \mathrm{y}\right)$ and sediment organic C content (6.3 wt.\%) to be $1.7 \mathrm{~mol} / \mathrm{m}^{2} / \mathrm{y}$. The sum of the $\mathrm{C}$ oxidation and $\mathrm{C}$ burial rates results in a C depositional flux of $28.9 \mathrm{~mol} / \mathrm{m}^{2} / \mathrm{y}$ or $346.8 \mathrm{~g} / \mathrm{m}^{2} / \mathrm{y}$. Deinema et al. ${ }^{59}$ have reported that polyphosphates can account for up to $20 \%$ of the dry weight of a bacterial cell. Conservatively assuming that bacteria and diatoms at the Effingham Inlet contain 2\% polyphosphates, an order of magnitude less than that reported by Deinema et $a l .{ }^{59}$ and assuming that most of the dry weight of a cell is $\mathrm{C}$, we can estimate that $6.9 \mathrm{~g}$ polyphosphate $\mathrm{P} / \mathrm{m}^{2} / \mathrm{y}$ are being deposited to the sediments. Considering a three-unit polyphosphate chain, the polyphosphate flux translates to a $\mathrm{P}$ flux of 0.08 moles $\mathrm{P} / \mathrm{m}^{2} / \mathrm{y}$, which is $12 \%$ of the measured benthic $\mathrm{P}$ flux at the anoxic site. This simple calculation shows that the release of $\mathrm{P}$ under anoxic conditions by polyphosphate accumulating benthic microorganisms can account for a part of the enhanced $\mathrm{P}$ fluxes observed at the anoxic site.

\section{CONCLUSIONS}

Results from solid-state ${ }^{31} \mathrm{P}$ NMR spectroscopy of demineralized sediments from two sites overlain by oxic and anoxic bottom waters in the Effingham Inlet reveal that $\mathrm{P}$ esters and phosphonates are the major organic $\mathrm{P}$ species present. However, there was no evidence of preferential remineralization of either organic $\mathrm{P}$ species with depth in these sediments. Biogenic inorganic $\mathrm{P}$ in the form of polyphosphates was seen only in the surface sediments from the oxic site. Ratios of $\mathrm{C}$ oxidation rates to benthic $\mathrm{P}$ fluxes strongly indicate the preferential remineralization of $\mathrm{P}$ relative to $\mathrm{C}$ at the anoxic site. This study provides evidence that $\mathrm{P}$ release during the utilization of polyphosphates by benthic microorganisms can account for a part of the enhanced P fluxes observed in sediments overlain by anoxic bottom waters.

\section{ACKNOWLEDGMENTS}

We would like to thank Dr. Johannes Leisen and Dr. Les Gelbaum at the Georgia Institute of Technology NMR center for their help with the NMR analyses. We also thank the captain and crew of R/V Clifford A. Barnes for sampling support during the cruise. We thank Dr. Tim Lyons and three anonymous reviewers for their insightful reviews. We would 
like to thank Susan Ryan for draft editing of the manuscript. This research was funded by the National Science Foundation.

${ }^{1}$ G. M. Fillippelli and M. L. Delaney, Geochim. Cosmochim. Acta 60, 1479 (1996).

${ }^{2}$ G. M. Fillippelli, Mar. Pet. Geol. 174, 307 (2001).

${ }^{3}$ P. N. Froelich, G. P. Klinkhammer, M. L. Bender, N. A. Luedtke, G. R. Heath, D. Cullen, B. Hartman, and V. Maynard, Geochim. Cosmochim. Acta 43, 1075-1090 (1979)

${ }^{4}$ E. D. Ingall and P. Van Cappellen, Geochim. Cosmochim. Acta 54, 373 (1990).

${ }^{5}$ K. C. Ruttenberg and R. A. Berner, Geochim. Cosmochim. Acta 57, 991 (1993).

${ }^{6}$ B. Sundby, C. Gobeil, N. Silverberg, and A. Mucci, Limnol. Oceanogr. 37, 1129 (1992)

${ }^{7}$ T. M. Lenton and A. J. Watson, Global Biogeochem. Cycles 14, 225 (2000).

${ }^{8}$ T. M. Lenton and A. J. Watson, Global Biogeochem. Cycles 14, 249-268 (2000).

${ }^{9}$ P. Van Cappellen and E. D. Ingall, Science 271, 493 (1996).

${ }^{10}$ P. Van Cappellen and E. D. Ingall, Paleoceanography 9, 677 (1994).

${ }^{11}$ K. Wallmann, Global Biogeochem. Cycles 17, 18 (2003).

${ }^{12}$ A. S. Colman and H. D. Holland, SEPM Special Publication 66, 53 (2000).

${ }^{13}$ E. D. Ingall and R. A. Jahnke, Geochim. Cosmochim. Acta 58, 2571 (1994).

${ }^{14}$ J. M. McManus, W. M. Berelson, K. H. Coale, K. S. Johnson, and T. E. Kilgore, Geochim. Cosmochim. Acta 61, 2891 (1997).

${ }^{15}$ E. D. Ingall and R. A. Jahnke, Mar. Pet. Geol. 139, 219 (1997).

${ }^{16}$ E. D. Ingall, L. Kolowith, T. Lyons, and M. Hurtgen, Am. J. Sci. 305, 240 (2005).

${ }^{17}$ A. E. Murphy, B. B. Sageman, and D. J. Hollander, Geology 28, 427 (2000).

${ }^{18}$ A. E. Murphy, B. B. Sageman, D. J. Hollander, T. W. Lyons, and C. E. Brett, Paleoceanography 15, 280 (2000).

${ }^{19}$ S. T. Petsch and R. A. Berner, Am. J. Sci. 298, 246 (1998).

${ }^{20} \mathrm{C}$. P. Slomp, J. Thomson, and G. J. De Lange, Geochim. Cosmochim. Acta 66, 1171 (2002)

${ }^{21}$ L. D. Anderson, M. L. Delaney, and K. L. Faul, Global Biogeochem. Cycles 15, 65 (2001).

${ }^{22}$ C. R. Benitez-Nelson, L. O'Neill, L. Kolowith, P. Pellechia, and R. Thunell, Limnol. Oceanogr. 49, 1593 (2004).

${ }^{23}$ M. L. Delaney, Global Biogeochem. Cycles 12, 563 (1998).

${ }^{24}$ B. Bostrom, J. M. Andersen, S. Fleischer, and M. Jansson, Hydrobiologia 170, 229 (1988)

${ }^{25}$ C. de Montigny and Y. T. Prairie, Hydrobiologia 253, 141 (1993).

${ }^{26}$ R. Gächter, J. S. Meyer, and A. Mares, Limnol. Oceanogr. 33, 1542 (1988).

${ }^{27}$ M. Hupfer, B. Rube, and P. Schmeider, Limnol. Oceanogr. 49, 1 (2004).
${ }^{28}$ B. Sundby, L. G. Anderson, P. O. J. Hall, A. Iverfeldt, M. M. R. Van Der Loeff, and S. F. G. Westerlund, Geochim. Cosmochim. Acta 50, 1282 (1986).

${ }^{29}$ H. N. Schulz and H. D. Schulz, Science 307, 416 (2005).

${ }^{30}$ R. Carman, G. Edlund, and C. Damberg, Chem. Geol. 163, 101 (2000).

${ }^{31}$ M. T. Hurtgen, T. W. Lyons, E. D. Ingall, and A. M. Cruse, Am. J. Sci. 299, 556 (1999).

${ }^{32}$ Y. Gélinas, J. A. Baldock, and J. I. Hedges, Org. Geochem. 32, 677 (2001).

${ }^{33}$ K. I. Aspila, H. Agemian, and A. S. Y. Chau, Analyst (Cambridge, U.K.) 101, 187 (1976)

${ }^{34}$ J. I. Hedges and J. H. Stern, Limnol. Oceanogr. 29, 657 (1984).

${ }^{35}$ L. Solórzano and J. D. H. Strickland, Limnol. Oceanogr. 13, 515 (1968).

${ }^{36}$ B. J. Cade-Menun and C. M. Preston, Soil Sci. 161, 101 (1996).

${ }^{37}$ A. Thomson-Bulldis and D. Karl, Limnol. Oceanogr. 43, 1565 (1998).

${ }^{38}$ D. W. de Haas, M. C. Wentzel, and G. A. Ekama, Water SA 26, 453 (2000).

${ }^{39}$ D. M. Karl and K. Björkman, Dynamics of DOP (Academic, New York, 2002).

${ }^{40} \mathrm{M}$. A. Wilson, NMR Techniques and Applications in Geochemistry and Soil Chemistry (Pergamon, Oxford, 1987).

${ }^{41}$ L. L. Clark, Ph.D. thesis, University of Texas at Austin, 2000.

${ }^{42}$ M. A. Nanny and R. A. Minear, Mar. Pet. Geol. 139, 77 (1997).

${ }^{43}$ A. Paytan, B. J. Cade-Menum, K. McLaughlin, and K. L. Faul, Mar. Chem. 82, 55 (2003).

${ }^{44}$ B. L. Turner, N. Maheiu, and L. M. Condron, Soil Sci. Soc. Am. J. 67, 497 (2003)

${ }^{45}$ J. I. Hedges, J. A. Baldock, Y. Gelinas, C. Lee, M. L. Peterson, and S. G. Wakeham, Mar. Chem. 78, 47 (2002).

${ }^{46}$ P. Sannigrahi, E. D. Ingall, and R. Benner, Deep-Sea Res. (in press).

${ }^{47}$ E. D. Ingall, P. A. Schroeder, and R. A. Berner, Geochim. Cosmochim. Acta 58, 2571 (1990).

${ }^{48}$ R. L. Bieleski, Annual Reviews in Plant Physiology 24, 225 (1973).

${ }^{49}$ P. V. Sundareshwar, J. T. Morris, P. J. Pellechia, H. J. Cohen, D. E. Porter, and B. C. Jones, Limnol. Oceanogr. 46, 1570 (2001).

${ }^{50}$ S. V. Kononova and M. A. Nesmeyanova, Biochemistry (Mosc.) 67, 187 (2002).

${ }^{51}$ N. G. Ternan, J. W. McGrath, G. McMullan, and J. P. Quinn, World J. Microbiol. Biotechnol. 14, 635 (1998).

${ }^{52}$ K. L. Laarkamp, Ph.D. thesis, Massachusetts Institute of Technology, 2000.

${ }^{53}$ M. A. Nesmeyanova, Biochemistry (Mosc.) 65, 309 (2000).

${ }^{54}$ D. Davelaar, Water Sci. Technol. 21, 1711 (1989).

${ }^{55}$ J. D. Schuffert, R. A. Jahnke, M. Kastner, J. Leather, A. Sturz, and M. R. Wing, Geochim. Cosmochim. Acta 58, 5001 (1994).

${ }^{56}$ P. Van Cappellen and R. A. Berner, Geochim. Cosmochim. Acta 55, 1219 (1991).

${ }^{57}$ A. S. Chang and R. T. Patterson, Palaios 18, 477 (2003).

${ }^{58}$ K. Pettersson, Arch. Hydrobiology 89, 54 (1980).

${ }^{59}$ M. H. Deinema, L. H. A. Habets, J. Scholten, E. Turkstra, and H. A. A. M. Webers, FEMS Microbiol. Lett. 9, 275 (1980) 